\title{
PRELIMINARY COMPUTATIONAL FLUID DYNAMICS (CFD) SIMULATION OF EIIB PUSH BARGE IN SHALLOW WATER
}

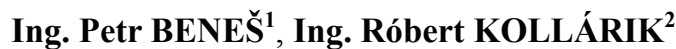 \\ ${ }^{1}$ Krašovice 130, 33013 \\ ${ }^{2}$ Jesenského 2, 90301 Senec
}

\begin{abstract}
This study presents preliminary CFD simulation of EIIb push barge in inland conditions using CFD software Ansys Fluent. The RANSE (Reynolds Averaged Navier-Stokes Equation) methods are used for the viscosity solution of turbulent flow around the ship hull. Different RANSE methods are used for the comparison of their results in ship resistance calculations, for selecting the appropriate and removing inappropriate methods. This study further familiarizes on the creation of geometrical model which considers exact water depth to vessel draft ratio in shallow water conditions, grid generation, setting mathematical model in Fluent and evaluation of the simulations results.
\end{abstract}

KEYWORDS: EIIb push barge, CFD simulation, RANSE methods, hybrid mesh, boundary conditions, ship resistance

\section{INTRODUCTION}

Assessment of ship resistance started to gain importance with the advent of machinepropelled ships in the early nineteenth century. The dependence of ship resistance on velocity was necessary for calculating the required power of the propulsion unit. There are three approaches known for the assessment of the ship resistance, i.e. analytical methods, model tests in basins and Computational Fluid Dynamics (CFD).

The analytical methods are the oldest, but the calculation is very complicated with a number of simplifications and limitations. Therefore, these methods are still rather applicable to the research and the understanding of flow principles, instead of practical calculations of ship resistance. The model tests in basins are the most applicable methods for the assessment of ship resistance. There was a lot of empirical formulas created from the systematically made model tests, which are valid for different types of vessels. However, these tests are too expensive and timeconsuming. The third and the most recent approach is Computational Fluid Dynamics (hereinafter referred to as CFD). There was necessary mutual cooperation of several disciplines such as mathematics, physics and information technology for the development of this method. CFD simulation gained larger scale acceptance in the 90's and has sometimes replaced experiments in many fields today. The advantage of CFD simulation is lower costs and shorter development time needed to create a computer simulation compared with model tests. Its disadvantage is in the diversity of these methods and mathematical models for turbulent flow. As a consequence there are common considerations about their accuracy and reliability. It introduces a certain conservatism and unwillingness to use these methods and to replace experiments by them. Therefore a lot of comparative studies are made between CFD simulation results and the model tests results and of course comparisons between different turbulence models. In some countries the CFD simulations have commonly been integrated into project of every new vessel, especially in the design of seagoing ships. This approach for assessing the ships resistance by using CFD simulations is also a content of this study. The study aims at developing the process and selection of appropriate 
methods for creating the geometrical model, setting-up the mathematical model and creating the preliminary CFD simulation with the CFD software Ansys Fluent. It will be applied in the case of EIIb push barge in shallow water, which is more interesting for inland countries such as Slovakia.

\section{GEOMETRY AND GRID CREATION}

3D model of the EIIb push barge hull was created using Catia software according to the dimensions (in Tab.1) and shapes defined in the lines plan seen in Fig. 1. The hull geometry was

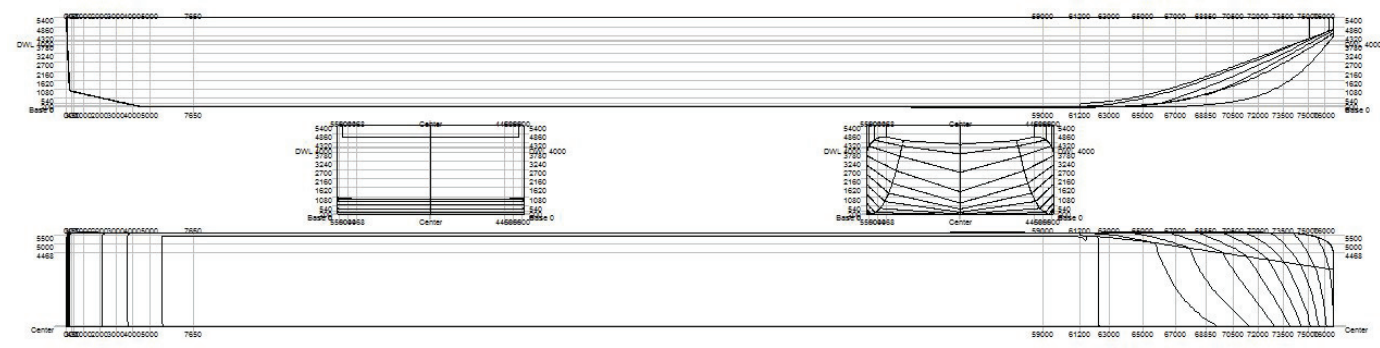

Fig.1: EIIb push barge linesplan

imported into the ANSYS Workbench. The rectangular volume around the body was completed here and split by plane in the water surface level. The water surface has shared geometry for both parts. Each of them represent one domain, i.e. water and air. The geometry was created for the case of $4 \mathrm{~m}$ draft and $7.5 \mathrm{~m}$ water depth and it was made at a scale of 1:16 to conserve computational time.

\begin{tabular}{|c|c|c|}
\hline Parameter & Push barge & $\begin{array}{c}\text { Push barge } \\
\text { model }\end{array}$ \\
\hline $\mathrm{L}[\mathrm{m}]$ & 76.5 & 4.781 \\
\hline $\mathrm{B}[\mathrm{m}]$ & 11.32 & 0.707 \\
\hline $\mathrm{T}[\mathrm{m}]$ & 4 & 0.25 \\
\hline $\mathrm{Cb}[-]$ & 0.937 & 0.937 \\
\hline $\mathrm{Cp}[-]$ & 0.938 & 0.938 \\
\hline $\mathrm{Cm}[-]$ & 0.996 & 0.996 \\
\hline $\mathrm{V}\left[\mathrm{m}^{3}\right]$ & 3236 & 0.79 \\
\hline $\mathrm{Sw}\left[\mathrm{m}^{2}\right]$ & 1449.1 & 5.66 \\
\hline
\end{tabular}

Tab. 1: EIIb hull and model parameters

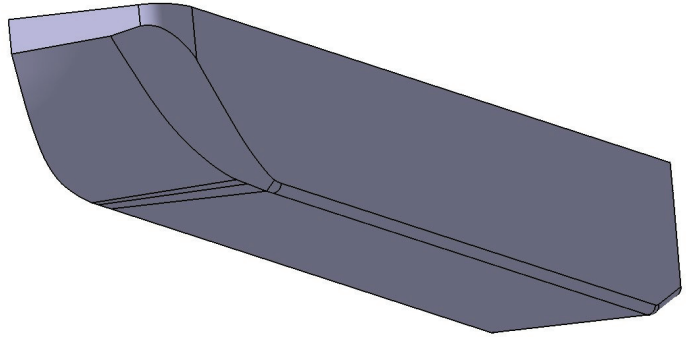

Fig. 2: EIIb push barge 3D Catia model

The water depth to ship draft ratio exactly given by the geometry allows the influence of shallow water on ship resistance and wave system generated by ship motion to be simulated. The domain must be large enough in the horizontal direction to prevent the influence of flow by boundaries, but the maximum size of the domain is limited by computer performance. It is therefore necessary to find a compromise. The CFD simulation were carried out for a half domain with half ship due to symmetry of the flow. Then discretization of this domain follows.

The grid quality is an important issue in free-surface flows . Generally a fine grid around the hull surface is desirable. The boundary layer, which is relatively thin, must be discretized with a mesh having a "not too large" aspect ratio. Furthermore, the free-surface flow requires a fine grid around the water surface. Fluent uses a cell-centered finite volume method and can utilize discrete volume elements that are constructed by a various number of sides. Generally they are structured 
and unstructured meshes. The structured grid is historically older, contains blocks and general hexahedrons. Benefits of the structured grids are greater accuracy of solution and saving computational performance. Disadvantages are problematic discretization of curved and more complicated geometries and problematic cell sizing. The unstructured grid contains tetrahedrons, pyramids and prismatic cells. It is suitable for complicated geometry and local sizing, which ensures good quality of mesh and combination of this cell types allows us to create the optimal grid. A hybrid mesh was used for discretization of EIIb push barge model, which can be seen in Fig. 3. It contains tetrahedral cells near the hull, where it is necessary to have a small volume
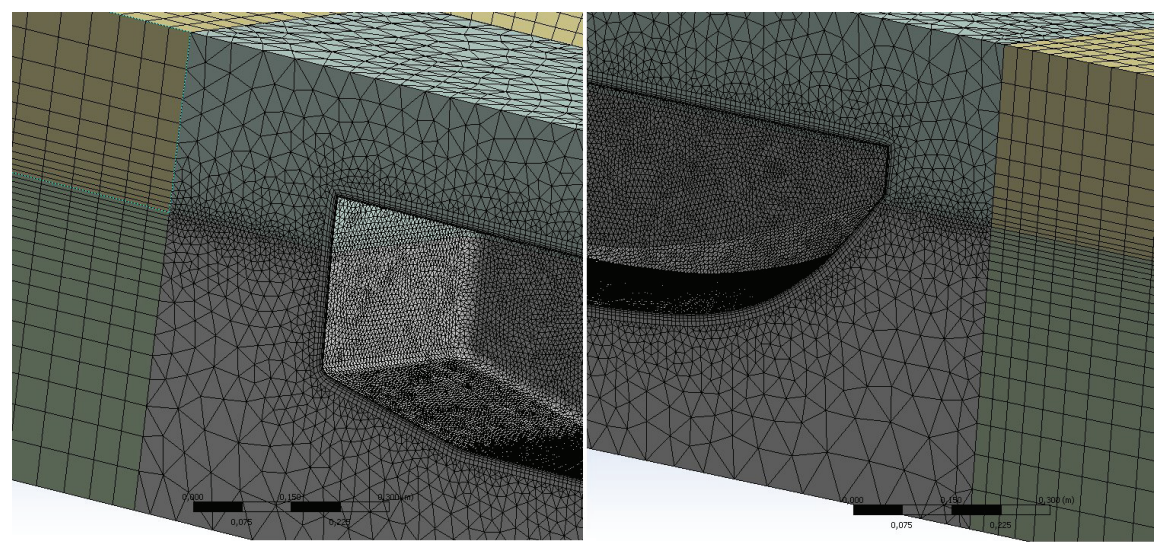

Fig. 3: Mesh of aft (left) and fore of push barge

elements. Structured mesh is used at a greater distance. This hybrid mesh contains about 2.9 million cells. About $95 \%$ of the cells form unstructured mesh which is concentrated in $2 \%$ of the volume of domain near the hull and boundary layer. The remaining 5\% form structured mesh occupying a larger part of the domain volume. This arrangement and hybrid mesh has less requirements for the number of cells and ultimately for computer performance in comparison with cases where the same domain would be meshed only by tetrahedral cells with the same sizing. Geometry with this discretization should have about 15 million cells and should need about six times more computational time because of free-surface mesh requirements.

\section{MATHEMATICAL MODEL SETTINGS USING FLUENT}

The following assumptions were used for mathematical model settings:

- linear motion of push barge with constant speed

- water surface without waves and river flow

- flat waterway bottom without natural irregularities

- $\quad$ water depth to draft of push barge $-\mathrm{h} / \mathrm{T}=1.875$

The following boundary conditions presented in Fig. 4 were applied in CFD simulation using Fluent:

Water/air inlet

Water/air outlet

Waterway bottom

Side/top boundary Hull pressure-inlet

pressure-outlet

wall

wall

wall vessel speed, open channel, free-surface and bottom level defined

open channel, free-surface and bottom level defined moving wall with vessel speed stationary wall with zero viscous stress stationary wall 
Center line

symmetry condition

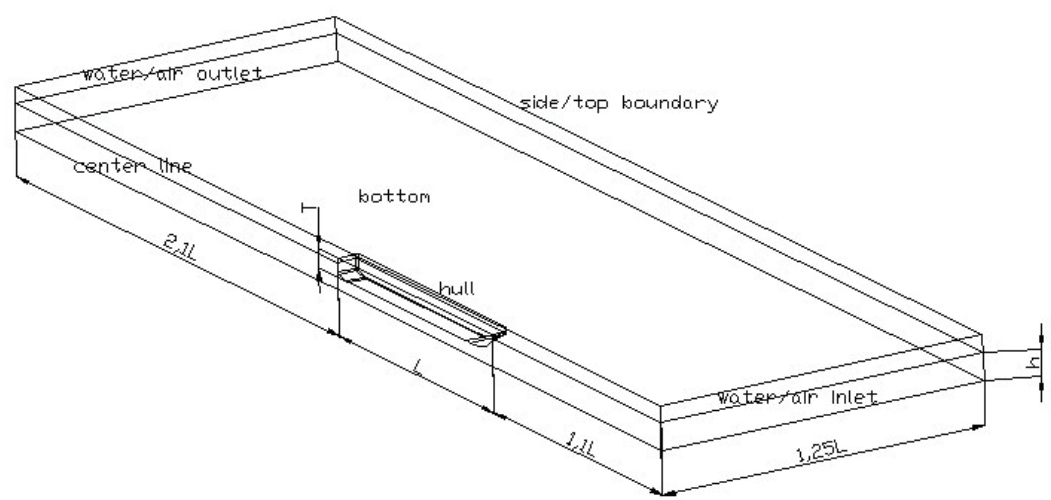

Fig. 4: Fluid domain dimensions and boundary conditions settings

Other model settings:

Solver:

Model:

pressure-based, steady

multiphase

Vol. fraction parameters:

Viscous:

open channel flow - implicit

Interpolation scheme:

RANSE (see Tab. 2), standard wall functions

pressure

presto

momentum

second order upwind

volume fraction

modified HRIC

$\mathrm{k}, \varepsilon$

QUICK

\section{RESULTS}

The simulation is made for a $3.97 \mathrm{~m} / \mathrm{s}$ velocity of the push barge, which is equivalent to $0.99 \mathrm{~m} / \mathrm{s}$ velocity of the push barge model. The Spalart-Almaras, RNG k-epsilon, realizable k-epsilon, SST k-omega and Reynolds stress viscous models were used. The Spalart-Almaras viscous model had convergence problems and was removed. This model was designed specifically for aerospace and probably is not too suitable for multiphase open channel flow. The results of the other four models are presented in Tab. 2. and includes conversion of total resistance from model simulation to real vessel by Froude method using ITTC 57 formula of friction resistance coefficient. where the Froude depth value can be given by:

$$
F_{r h}=v / \sqrt{(g * h)}
$$

(1)

Froude depth number of all cases is 0.463 . The graphical results are presented in the following 
SCIENTIFIC PROCEEDINGS 2011, Faculty of Mechanical Engineering, STU in Bratislava Vol. 19, 2011, pp. 67-73, DOI: 10.2478/v10228-011-0012-1

\begin{tabular}{|c|c|c|c|c|c|}
\hline \multicolumn{6}{|c|}{ Push barge model values } \\
\hline Viscous model & & RNG k- $\varepsilon$ & Realizable k- $\varepsilon$ & SST k- $\omega$ & RSM \\
\hline Pressure resistance & $R_{p}[N]$ & 11.51 & 13.67 & 8.31 & 13.54 \\
\hline Viscous resistance & $R_{v}[N]$ & 5.34 & 5.72 & 4.89 & 6.85 \\
\hline Total resistance & $\mathrm{R}_{\mathrm{t}}[\mathrm{N}]$ & 16.85 & 19.4 & 13.2 & 20.33 \\
\hline \multicolumn{6}{|l|}{ Push barge values } \\
\hline Viscous model & & RNG k- $-\varepsilon$ & Realizable k- $\varepsilon$ & SST k- $\omega$ & RSM \\
\hline Residual resistance & $\mathrm{R}_{\mathrm{r}}[\mathrm{kN}]$ & 28.45 & 38.89 & 13.5 & 42.7 \\
\hline Friction resistance & $R_{f}[k N]$ & 20.91 & 20.91 & 20.91 & 20.91 \\
\hline
\end{tabular}

Tab. 2: Resistance results of model and real vessel

illustrations (Fig, 5, 6, 7) of which it appears that SST k- $\omega$ and Reynolds stress viscous model give more realistic results. These models are more complicated as $\mathrm{k}-\varepsilon$ models, but they have greater requirements for computer performance and time consumption. If it is true, a comparison with the results of practical measurements will be the focus in future work.

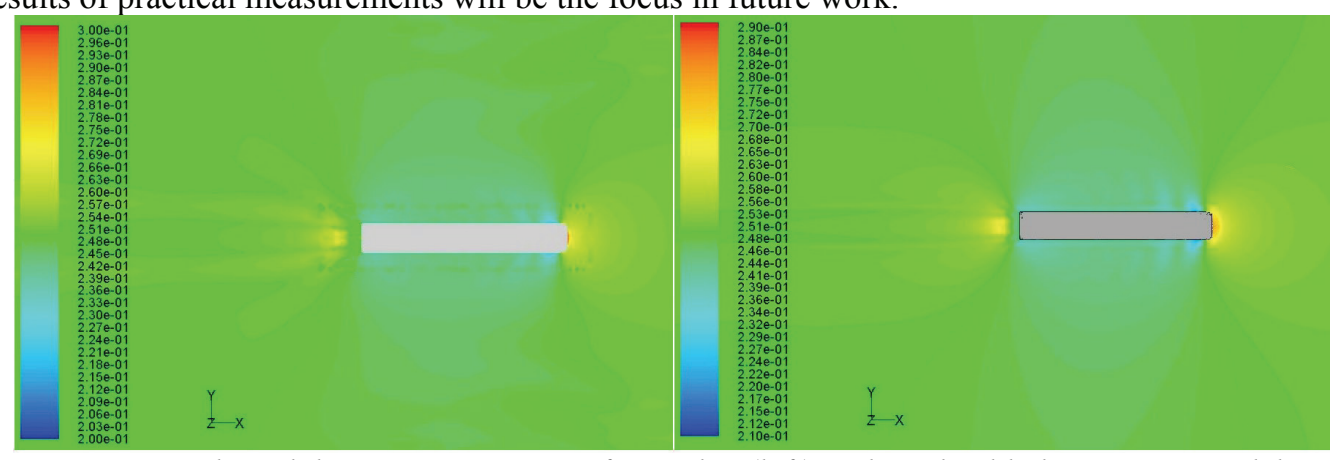

Fig. 5: EIIb push barge wave system of $R N G k-\varepsilon$ (left) and Realizable $k-\varepsilon$ viscous model

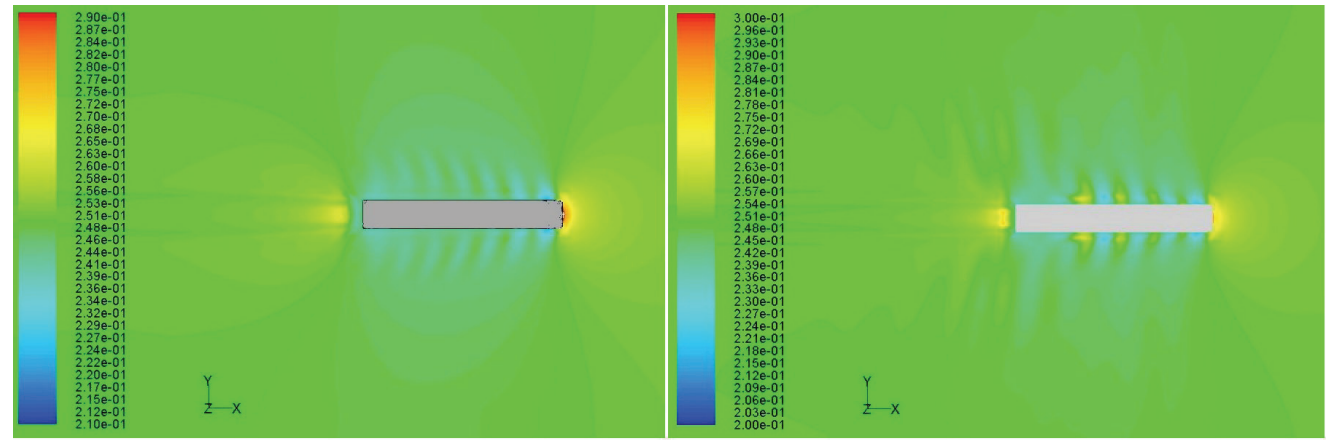

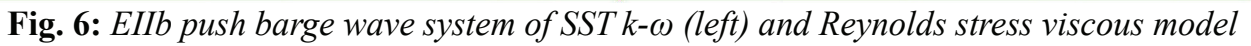




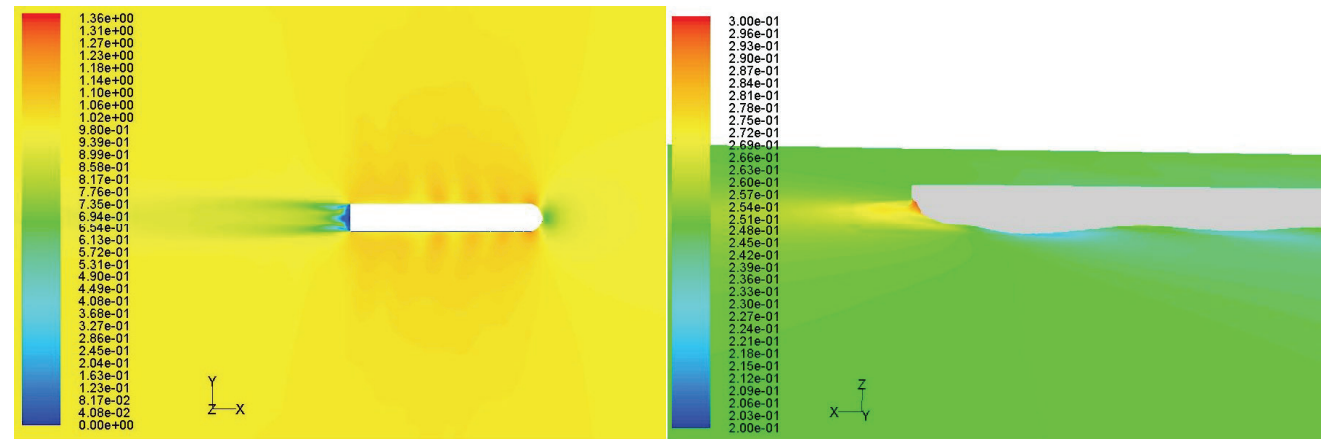

Fig. 7: Reynolds stress viscous model - velocity magnitude contours on horizontal plane $1.6 \mathrm{~m}$ below water surface (left) and wave system around the vessel fore

\section{CONCLUSION}

The preliminary CFD simulation of EIIb push barge in shallow water is the first part of the work. Its purpose was to learn how to prepare the geometric model, suitable grid generation and setting-up the mathematical model in CFD software Ansys Fluent. Future plans focus on the comparison of these simulation results using different RANSE methods, with the results of practical measurements. This comparisons will be made for a number of velocities to create the resistance curves and of course for different ship drafts and different depth to draft ratios. It is important for determining navigation problems in shallow water and the influence of shallow water on particular resistance components, total ship resistance and wave system generated by the sailing vessel. It is necessary for the development and optimization of hull shapes, dimension ratios, hull coefficients and their dependence on velocity and waterway depth without using expensive and time-consuming model in basin tests. Simulations of existing vessels and comparison of their results with results of practical measurements are unavoidable to verify the accuracy of the CFD methods.

\section{REFERENCES}

[1] Ansys, Inc. ANSYS FLUENT 12.0/12.1 Documentation

[2] Ansys, Inc. (2009): Introductory Fluent Training

[3] BANAVAN, A. A. ; AHMED, Y. M. (2006): Use of Computational Fluid Dynamics for the Calculation of Ship Resistance and its Variations with the Ship Hull Form Parameters, AEJ, Vol.45, Faculty of Engineering Alexandria University, Alexandria

[4] JACHOWSKI, J. (2008): Assessment of Ship Squat in Shallow Water Using CFD, Archive of Civil and Mechanical Engineering, Vol. VIII, 2008, No. 1, Gdansk University of Technology, Gdansk

[6] KOZUBKOVÁ, M. ; DRÁBKOVÁ, S. (2003): Numerické modelování proudění - FLUENT I, VŠB - TU Ostrava, Ostrava, $124 \mathrm{~s}$

[7] LÖHNER, R. (2008): Applied CDF Techniques, ISBN 978-0-470-51907-3, John Wiley \& Sons, Ltd, Chichester

[8] MAKI, K. J. ; DOCTORS, J. L. et al.: Conceptual Design and Hydrodynamic Analysis of a High-Speed Sealift Adjustable-Length Trimaran, HSSL

[9] SENOCAK, I. ; IACCARINO, G. (2005): Progress Towards RANS Simulation of Free-surface Flow around Modern Ships, Center for Turbulence Research, Annual Research Briefs 2005

[10] TICHÝ, J.- PATEK, P. (1987): Teória lode, Vydavatel'stvo SVŠT, Bratislava, 355 s 
SCIENTIFIC PROCEEDINGS 2011, Faculty of Mechanical Engineering, STU in Bratislava Vol. 19, 2011, pp. 67-73, DOI: 10.2478/v10228-011-0012-1

Versuchsanstalt für Binnenschiffbau e. V. (1985): Systematische Wiederstands- und Propulsionversuche mit Kielspant-Leichterverbänden auf begrenzten Wassertiefen, Bericht Nr. 1146, Duisburg

[11] WAN, D. - SHEN, Z. - MA, J. (2010): Numerical Simulations of Viscous Flows around Surface Ship by Level Set Method, $9^{\text {th }}$ International Conference on Hydrodynamics, Shanghai Jiao Tong University, Shanghai

[12]All illustrations and tables was created by authors of this paper 